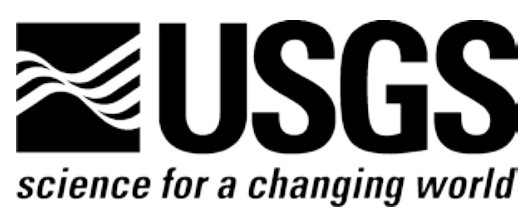

Prepared in cooperation with the U.S. Fish and Wildlife Service

\title{
Timing of Warm Water Refuge Use in Crystal River National Wildlife Refuge by Manatees-Results and Insights From Global Positioning System Telemetry Data
}

By Daniel H. Slone, Susan M. Butler, James P. Reid, and Catherine G. Haase

Open-File Report 2017-1146

U.S. Department of the Interior

U.S. Geological Survey 


\title{
U.S. Department of the Interior \\ RYAN K. ZINKE, Secretary
}

\section{U.S. Geological Survey William H. Werkheiser, Acting Director}

\author{
U.S. Geological Survey, Reston, Virginia: 2017
}

For more information on the USGS-the Federal source for science about the Earth, its natural and living resources, natural hazards, and the environment-visit https://www.usgs.gov/ or call 1888-ASK-USGS (1-888-275-8747).

For an overview of USGS information products, including maps, imagery, and publications, visit https://store.usgs.gov/.

Any use of trade, firm, or product names is for descriptive purposes only and does not imply endorsement by the U.S. Government.

Although this information product, for the most part, is in the public domain, it also may contain copyrighted materials as noted in the text. Permission to reproduce copyrighted items must be secured from the copyright owner.

Suggested citation:

Slone, D.H., Butler, S.M., Reid, J.P., and Haase, C.G., 2017, Timing of warm water refuge use in Crystal River National Wildlife Refuge by manatees-Results and insights from Global Positioning System telemetry data: U.S. Geological Survey Open-File Report 2017-1146, 17 p., https://doi.org/10.3133/ofr20171146.

ISSN 2331-1258 (online) 


\section{Acknowledgments}

The analysis of these data was supported by a generous grant from the U.S. Fish and Wildlife Service (Agreement \#4500110336). We thank Joyce Palmer, Joyce Kleen, and Trisha Phy at Crystal River National Wildlife Refuge for sharing their expertise. Manatee telemetry data were gathered under the authority of U.S. Fish and Wildlife Service Research Permit MA791721. Animal handling was conducted in accordance with Institutional Animal Care and Use Committee (IACUC) USGS/WARC 2016-03 and the Laboratory Animal Welfare Act of 1966 (P.L. 89-544). Previous financial support was provided by the U.S. Geological Survey Wildlife and Environments Programs, and the Bureau of Ocean Energy Management under Interagency Agreement GM-13-07. 


\section{Contents}

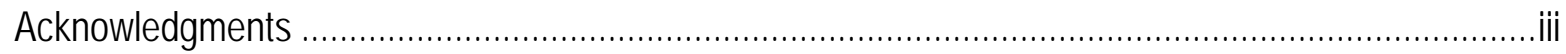

Abstract ……

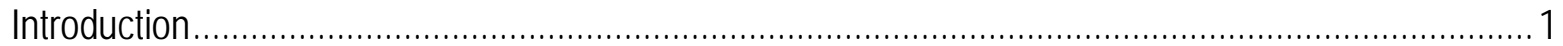

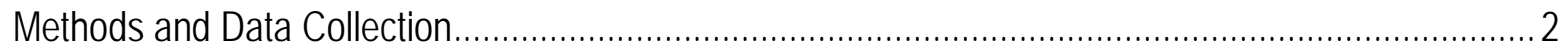

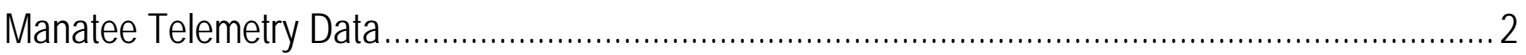

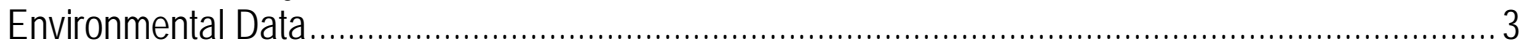

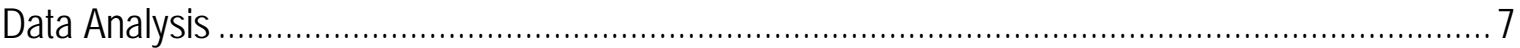

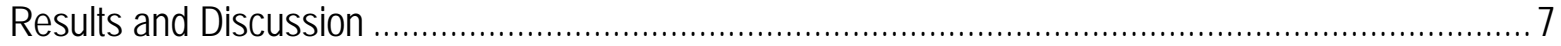

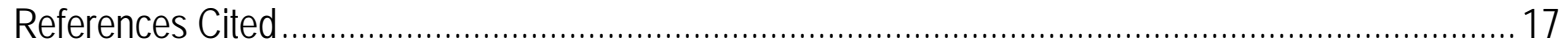

\section{Figures}

Figure 1. Map of the study area near Crystal River, Florida, indicating location of the bounding box used to select relevant manatee tracking data.

Figure 2. Map of Crystal River and Kings Bay, Florida, indicating locations of U.S. Geological Survey water-monitoring stations and polygons created to encompass Crystal and Salt Rivers, and Kings Bay.

Figure 3. Map showing locations of the springs with the highest manatees use in Kings Bay, Florida, and the spatial polygons used to isolate Global Positioning System locations of manatees using them.

Figure 4. Graph showing water temperatures recorded at the bottom of the water column from U.S. Geological Survey water-monitoring stations and from data loggers placed in the vicinity of springs during a cold front.

Figure 5. Graph showing example of tide stage in North American Vertical Datum of 1988 during 1 week at the mouth of Bagley Cove, Florida (U.S. Geological Survey station 02310747), compared to authors' data logger (Onset U20-001-02-TI) placed in the vicinity of Magnolia Spring, Florida.

Figure 6. Boxplots of manatee locations were recorded in each of seven location polygons in and around the Crystal River National Wildlife Refuge compared to Gulf water temperatures recorded from the Crystal River mouth, U.S. Geological Survey station 285531082412600.

Figure 7. Graph showing proportion of manatee Global Positioning System locations plotted in each of seven location polygons at a range of Gulf water temperatures recorded from the Crystal River mouth, Florida, U.S. Geological Survey station 285531082412600 .

Figure 8. Graph showing number of manatee Global Positioning System locations plotted in each of seven location polygons at a range of Gulf water temperatures recorded from the Crystal River mouth, Florida, U.S. Geological Survey station 285531082412600.

Figure 9. Graphs showing density of manatee Global Positioning System locations and movements relative to the four spring polygons by hour of the day and blocks of Gulf water temperatures recorded from the Crystal River mouth, Florida, U.S. Geological Survey station 285531082412600 
Figure 10. Graphs showing number of manatee Global Positioning System movements relative to the Three Sisters/ldiots Delight polygon at different blocks of Gulf water temperatures recorded at the Crystal River mouth, Florida, U.S. Geological Survey station 285531082412600, and tide stage at Magnolia Spring.

Figure 11. Graphs showing number of manatee Global Positioning System locations relative to the Three Sisters/ldiots Delight polygon at different blocks of Gulf water temperatures recorded at the Crystal River mouth, Florida, U.S. Geological Survey station 285531082412600, and tide stage at Magnolia Spring.

\section{Tables}

Table 1. Fitted parameters of equation 1 used to transform water-level data from level recostations in and around Kings Bay, Florida, to the level at Magnolia Spring, Fla.

\section{Conversion Factors}

U.S. customary units to International System of Units

\begin{tabular}{lccc} 
& Multiply & By & To obtain \\
\hline foot $(\mathrm{ft})$ & & 0.3048 & meter $(\mathrm{m})$ \\
\hline
\end{tabular}

Temperature in degrees Celsius $\left({ }^{\circ} \mathrm{C}\right)$ may be converted to degrees Fahrenheit $\left({ }^{\circ} \mathrm{F}\right)$ as follows:

$$
{ }^{\circ} \mathrm{F}=\left(1.8 \times{ }^{\circ} \mathrm{C}\right)+32 \text {. }
$$

\section{Datum}

Vertical coordinate information is referenced to the North American Vertical Datum of 1988 (NAVD 88). Horizontal coordinate information is referenced to the World Geodetic System 1984 (WGS 84).

\section{Abbreviations}

$\begin{array}{ll}\text { BOEM } & \text { Bureau of Ocean Energy Management } \\ \text { IACUC } & \text { Institutional Animal Care and Use Committee } \\ \text { CRNWR } & \text { Crystal River National Wildlife Refuge } \\ \text { GIS } & \text { geographic information system } \\ \text { GPS } & \text { Global Positioning System } \\ \text { MLLW } & \text { mean low-low water } \\ \text { MW } & \text { mean water } \\ \text { NOAA } & \text { National Oceanic and Atmospheric Administration } \\ \text { PTT } & \text { platform terminal transmitter } \\ \text { QFP } & \text { quick fix pseudoranging } \\ \text { USGS } & \text { U.S. Geological Survey }\end{array}$




\title{
Timing of Warm Water Refuge Use in Crystal River National Wildlife Refuge by Manatees-Results and Insights From Global Positioning System Telemetry Data
}

\author{
By Daniel H. Slone, Susan M. Butler, James P. Reid, and Catherine G. Haase
}

\begin{abstract}
Managers at the U.S. Fish and Wildlife Service Crystal River National Wildlife Refuge (CRNWR) desire to update their management plan regarding the operation of select springs including Three Sisters Springs. They wish to refine existing parameters used to predict the presence of federally threatened Trichechus manatus latirostris (Florida manatee) in the springs and thereby improve their manatee management options. The U.S. Geological Survey Sirenia Project has been tracking manatees in the CRNWR area since 2006 with floating Global Positioning System (GPS) satellite-monitored telemetry tags. Analyzing movements of these tagged manatees will provide valuable insight into their habitat use patterns.

A total of 136 GPS telemetry bouts were available for this project, representing 730,009 locations generated from 40 manatees tagged in the Gulf of Mexico north of Tampa, Florida. Dates from October through March were included to correspond to the times that cold ambient temperatures were expected, thus requiring a need for manatee thermoregulation and a physiologic need for warm water. Water level (tide) and water temperatures were obtained for the study from Salt River, Crystal River mouth, Bagley Cove, Kings Bay mouth, and Magnolia Spring. Polygons were drawn to subdivide the manatee locations into areas around the most-used springs (Three Sisters/Idiots Delight, House/Hunter/Jurassic, Magnolia and King), Kings Bay, Crystal/Salt Rivers and the Gulf of Mexico.

Manatees were found in the Crystal or Salt Rivers or in the Gulf of Mexico when ambient temperatures were warmer $\left(>20^{\circ} \mathrm{C}\right)$, while they were found in or near the springs (especially Three Sisters Springs) at colder ambient water temperatures. There was a trend of manatees entering springs early in the morning and leaving in the afternoon. There was a strong association of manatee movements in and out of the Three Sisters/Idiots Delight polygon with tide cycles: manatees were more likely to enter the Three Sisters/Idiots Delight polygon on an incoming tide, and leave the polygon on an outgoing tide. Both movement directions were associated with midtide. Future analysis will incorporate human activity and a finer spatial scale, including movements between Three Sisters Springs and Idiots Delight and nearby canals.
\end{abstract}

\section{Introduction}

Managers at U.S. Fish and Wildlife Service Crystal River National Wildlife Refuge (CRNWR) desire to update their management plan regarding the operation of select springs 
including the Three Sisters Springs. The current management plan includes guidelines on when Three Sisters Springs should be open or closed to the public, depending on when federally threatened Trichechus manatus latirostris (Florida manatees) would be most likely to use the warmer spring water to avoid exposure to debilitating cold periods. It focuses on a complex array of ancillary metrics - including ambient air temperature, Gulf of Mexico (hereafter, Gulf) water temperature, and tides - to predict manatee presence and avoid potential human/manatee conflict within Three Sisters Springs. The updated plan will require additional information to refine existing parameters used to predict manatee presence within Three Sisters Springs and thereby improve management options.

The U.S. Geological Survey (USGS) Sirenia Project has been tracking manatees in the CRNWR area with Global Positioning System (GPS) telemetry since 2006, and most of these animals have visited Three Sisters Springs multiple times to meet their thermoregulatory needs. These data — combined with environmental information such as water temperature and level in the Gulf, rivers and springs - can give a more precise view of manatee usage patterns relative to measurable ambient conditions.

\section{Methods and Data Collection}

Data for this project consisted of manatee location data derived from GPS telemetry tags, polygon layers of the water bodies in and around the CRNWR created in a geographic information system (GIS), and environmental data.

All manatee location data were collected by the authors from November 2006 to March 2017. Due to the sensitivity of location data of federally listed species, contact the authors for more information about availability. All GIS data layers were standardized to the World Geodetic System 1984 (WGS84 or EPSG4326) to match the native GPS datum.

Environmental data were collected by the authors and are available at https://www.sciencebase.gov (Slone, 2017) or obtained from publically accessible environmental stations maintained by the USGS at https://waterdata.usgs.gov and the National Oceanic and Atmospheric Administration (NOAA) at https://tidesandcurrents.noaa.gov. All level data were standardized to feet referenced to the North American Vertical Datum of 1988 (NAVD 88), and all temperature data were standardized to degrees Celsius $\left({ }^{\circ} \mathrm{C}\right)$.

\section{Manatee Telemetry Data}

Manatees were tagged with a floating satellite-monitored location and data collection telemetry tag that is effective for tracking and monitoring manatees in both freshwater and marine environments (Reid and others, 1995). The floating transmitter was connected to an adjustable belt attached around the base of the tail by a flexible nylon tether. Each tether had an engineered weak link with a breaking point that is varied based on animal size class and designed to break free if the transmitter becomes entangled. These telemetry tags (TMT-462 and the smaller TMT-464, Telonics)—with GPS receivers coupled with satellite monitored Argos platform terminal transmitters (PTTs) — have been the primary tracking device employed by researchers for application on manatees since the mid-2000s. The tags were programmed to periodically acquire GPS locations by using standard or quick fix pseudoranging (QFP) technology (Tomkiewicz and others, 2010) that are relayed to users through the Argos System satellite uplink. For tags used in this database, the rate of acquisition was generally programmed to 15-minute intervals. A saltwater switch synchronized GPS fixes and Argos transmissions 
during surfacings and enabled the tag to log dive data along with temperature and tag activity data. A greater than 96 percent success in obtaining an accurate GPS location fix each hour enabled us to document detailed movements and assign precise habitat-use patterns within the fine scale of inland waterways and coastal environments occupied by telemetered manatees (Marmontel and others, 2012).

Data from 136 GPS bouts were available for this project, defined as the time period from when a GPS transmitter was attached to a manatee to the time when it was replaced with another tag, the tag detached due to entanglement, or the tag stopped functioning. Only records from healthy, wild caught or free-tagged manatees were used for this project. These bouts included 730,009 locations generated from 40 manatees tracked in the Gulf north of Tampa, Florida. Approximately half of the manatees were tracked for a study on the habitat use and movements of manatees in the northern Gulf that was sponsored by the Bureau of Ocean Energy Management (BOEM) and the other half were tracked for other USGS studies.

Preliminary examination of the manatee GPS records showed a local use concentration area in the Gulf near Crystal River, and a bounding box was created to encompass this grouping (extent $=-82.850^{\circ}$ to $-82.570^{\circ}$ longitude, $28.830^{\circ}$ to $28.955^{\circ}$ latitude, fig. 1 ). All locations outside of this bounding box were excluded. Similarly, only dates from October through March were included to correspond to the times that cold ambient temperatures were expected, thus requiring a need for manatee thermoregulation and a physiologic need for warm water.

\section{Environmental Data} sites:

Water level (tide) and temperatures were obtained for the study period from the following

- Cedar Key: NOAA station 8727520, Cedar Key, Fla. Level data were reported every 15 minutes as feet above mean low-low water (MLLW) local datum, which is 1.80 feet (ft) above local datum at NAVD $88-4.06 \mathrm{ft}$ ). We subtracted $2.26 \mathrm{ft}$ from the recorded data to obtain water level in NAVD 88.

- Crystal River mouth: USGS station 285531082412600, Crystal River mouth at Shell Island near Crystal River, Fla. Level data were reported every 15 minutes as feet above NAVD 88 (fig. 2). Temperature data were reported every 15 minutes from the top and bottom of the water column.

- Salt River: USGS station 02310752, Salt River near Crystal River, Fla. Data are reported in feet above NAVD 88 (fig. 2). Temperature data were reported every 15 minutes from the top and bottom of the water column.

- Bagley Cove: USGS station 02310747, Crystal River at Bagley Cove near Crystal River, Fla. Data are reported in feet above local datum at NAVD $88-12.18 \mathrm{ft}$. We subtracted $12.18 \mathrm{ft}$ from the recorded data to obtain water level in NAVD 88 (fig. 1). Temperature data were reported every 15 minutes from the top and bottom of the water column.

- Kings Bay mouth: USGS station 02310742, Crystal River at mouth of Kings Bay, Fla. Data are reported in feet above NAVD 88 (fig. 1). Temperature data were reported every 15 minutes from the top and bottom of the water column.

- Magnolia Spring: Authors' data logger (HOBO U20-001-01-Ti; Onset Computer Corp., Bourne, Massachusetts) The data logger was attached to a CRNWR signpost to the northeast of the spring boil. Level data were reported every 10 minutes in meters above local datum. We converted to feet by multiplying by 3.28, then subtracted 3.97 to obtain mean water level (MW) at a local datum. Although this data logger was not surveyed to 
NAVD 88, we noted that MW of the local datum was within $0.03 \mathrm{ft}$ of MW at the nearest USGS station (mouth of Kings Bay). Temperature data were also reported every 10 minutes (Slone, 2017).

- Three Sisters Spring: Authors’ data logger (HOBO U22; Onset Computer Corp., Bourne, Mass.) placed in Three Sisters Springs from November 2014 through March 2015. It was attached to an existing metal post in the east lobe of the springs and was set to record temperature at a 10-minute interval (Slone, 2017).

A polygon layer was created to subdivide the manatee GPS locations into relevant water bodies and springs (fig. 3). Polygons were drawn manually around the most-used springs (Three Sisters/Idiots Delight, King (including Mullet’s Gullet and Tarpon Hole), House/Hunter/Jurassic, and Magnolia), including a buffer of 100 to 200 meters (m) to allow for GPS error. Note that the Three Sisters Springs polygon incorporated aggregation areas outside of the narrow entrance to the springs including the Three Sisters Springs Manatee Sanctuary at Idiots Delight \#1, Idiots Delight \#2 and approximately $350 \mathrm{~m}$ of the Three Sisters Springs canal. Larger polygons were drawn around Kings Bay to Bagley Cove, and Crystal River from Bagley Cove to the river mouth (fig. 2). Any manatee location that fell outside of these polygons but inside the bounding box was classified as a Gulf location.

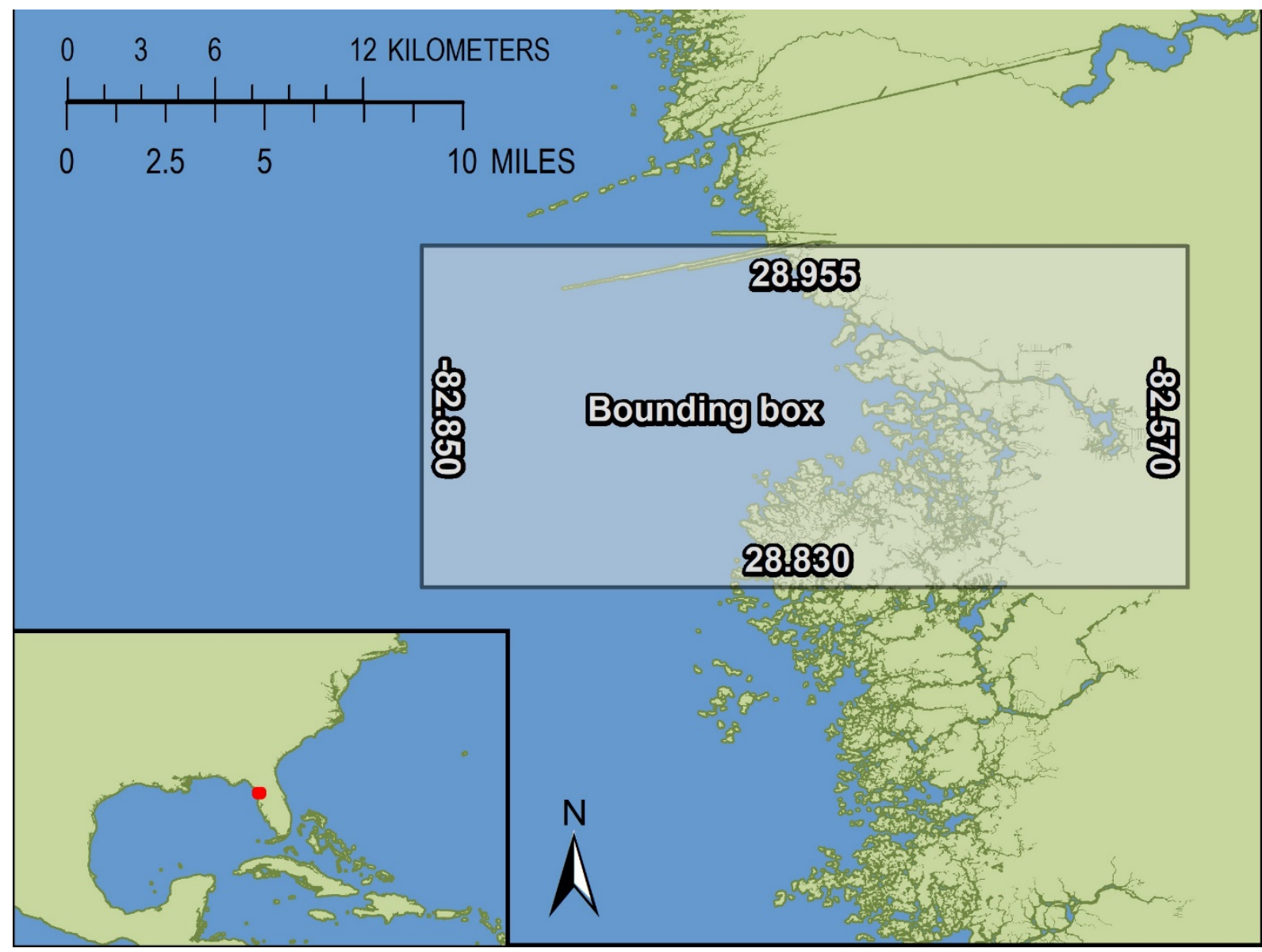

Figure 1. Map of the study area near Crystal River, Florida, indicating location of the bounding box used to select relevant manatee tracking data. 


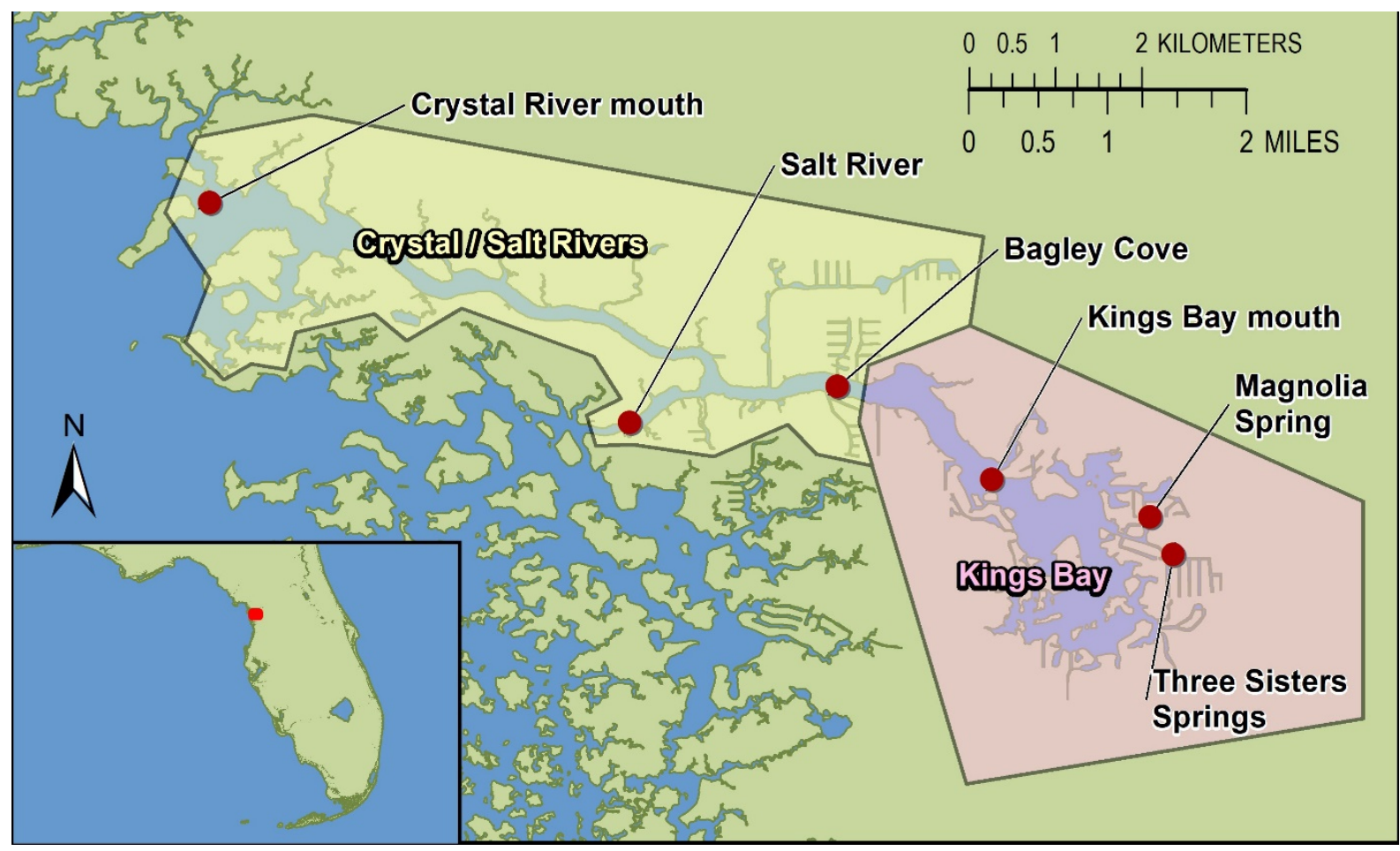

Figure 2. Map of Crystal River and Kings Bay, Florida, indicating locations of U.S. Geological Survey water-monitoring stations and polygons created to encompass Crystal and Salt Rivers, and Kings Bay. 


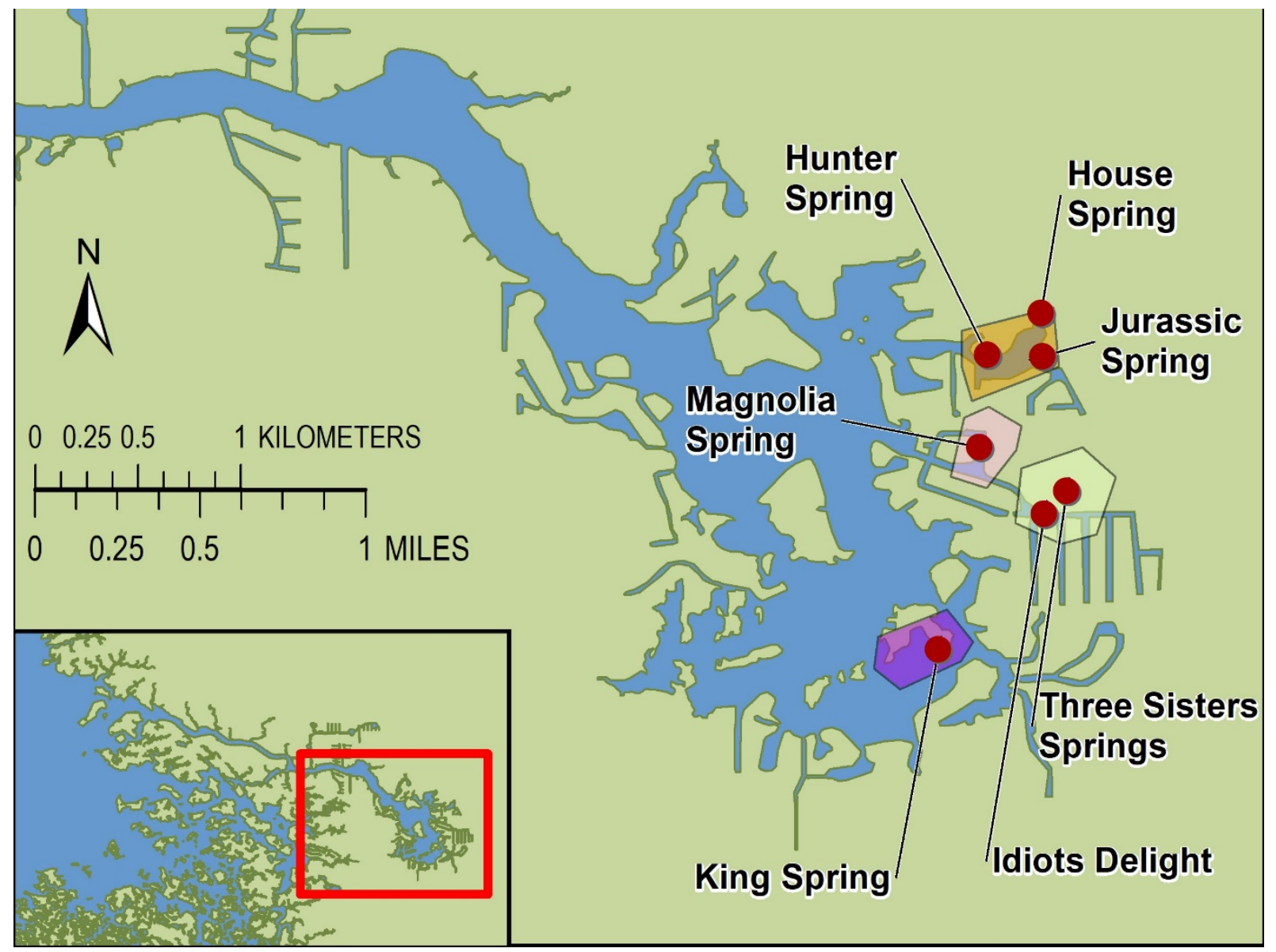

Figure 3. Map showing locations of the springs with the highest manatees use in Kings Bay, Florida, and the spatial polygons used to isolate Global Positioning System locations of manatees using them. 


\section{Data Analysis}

All data analyses and figures were produced with the statistical program R (Version 3.4.0; R Core Team, 2017). The purpose of these analyses was to illustrate patterns and trends and not to test any particular hypothesis. As such, most analyses will be descriptive and graphical rather than quantitative.

To evaluate the correlations between our Magnolia Spring water-level sensor and the USGS and NOAA water stations, Pearson's correlation coefficients were calculated between data from the data logger and each water-level station by using function cor. Next, models to translate each water-level station to Magnolia Spring were fitted using the following relation for each hour, $t$, in the data:

$$
\text { level(Magnolia) } \left.)_{t}-(\text { mean }+a m p * \text { level(station })_{(t+l a g)}\right)=0
$$

where

lag is difference in timing of the peak amplitude between Magnolia Spring data and the data for each station, in hours;

mean is the difference in mean water level between the Magnolia Spring data and the data for each station, in feet; and

amp is a correction for the amplitude between the Magnolia Spring data and the data for each station.

Parameters for this model were numerically optimized by using function optim with the L-BFGS-B method (Byrd and others, 1995) by optimizing the sum of squares of all times $t$. Correlations were again calculated between the resulting modeled levels and Magnolia Spring data levels.

Raw and modeled water-level data and temperature data were merged with the manatee telemetry database by date/time by, using the package data.table (Dowle and Srinivasan, 2017) with parameter " roll = "nearest" ". Any environmental data that did not match within 1 hour of any telemetry location was discarded.

Movements among polygons were calculated from successive GPS locations. For example, if a manatee was located in the Three Sisters/Idiots Delight polygon, and then subsequently located in the Kings Bay polygon, the movement would be recorded as "Leaving Three Sisters Springs.” Conversely, a manatee that was located in the Three Sisters/Idiots Delight polygon and the successive location was in the same polygon, it would be recorded as "In Three Sisters Springs." Similar locations and movements were calculated for all polygons individually and also for the combination of all spring polygons together.

Plots showing relationships among time of day, Gulf water temperature, tide, and manatee locations and movements were generated with the package ggplot2 (Wickham, 2009).

\section{Results and Discussion}

After clipping the manatee GPS records to the preliminary bounding box and winter time period, 215,000 locations from 33 manatees remained in the database. All 33 manatees used at least one of the springs within Kings Bay during the winter, and 30 used Three Sisters Springs. Approximately 50 percent of the GPS locations $(101,000)$ in the database were within Kings Bay 
including the springs, and 10 percent of the locations $(22,000)$ were within the Three Sisters/Idiots Delight polygon.

Water temperatures at the recording stations differed across the study area during cold periods (fig. 4). As expected, the large springs such as Three Sisters Springs and Magnolia Spring maintained a stable temperature of approximately $23^{\circ} \mathrm{C}$ regardless of ambient conditions. The mouth of Kings Bay, the closest water temperature station to the springs, had the smallest drop in temperature of all the sites outside of the springs during cold fronts, whereas the stations farthest away (mouth of Crystal River and Salt River) showed the greatest drop. The Crystal River mouth station was selected to represent ambient Gulf water temperature for all analyses.

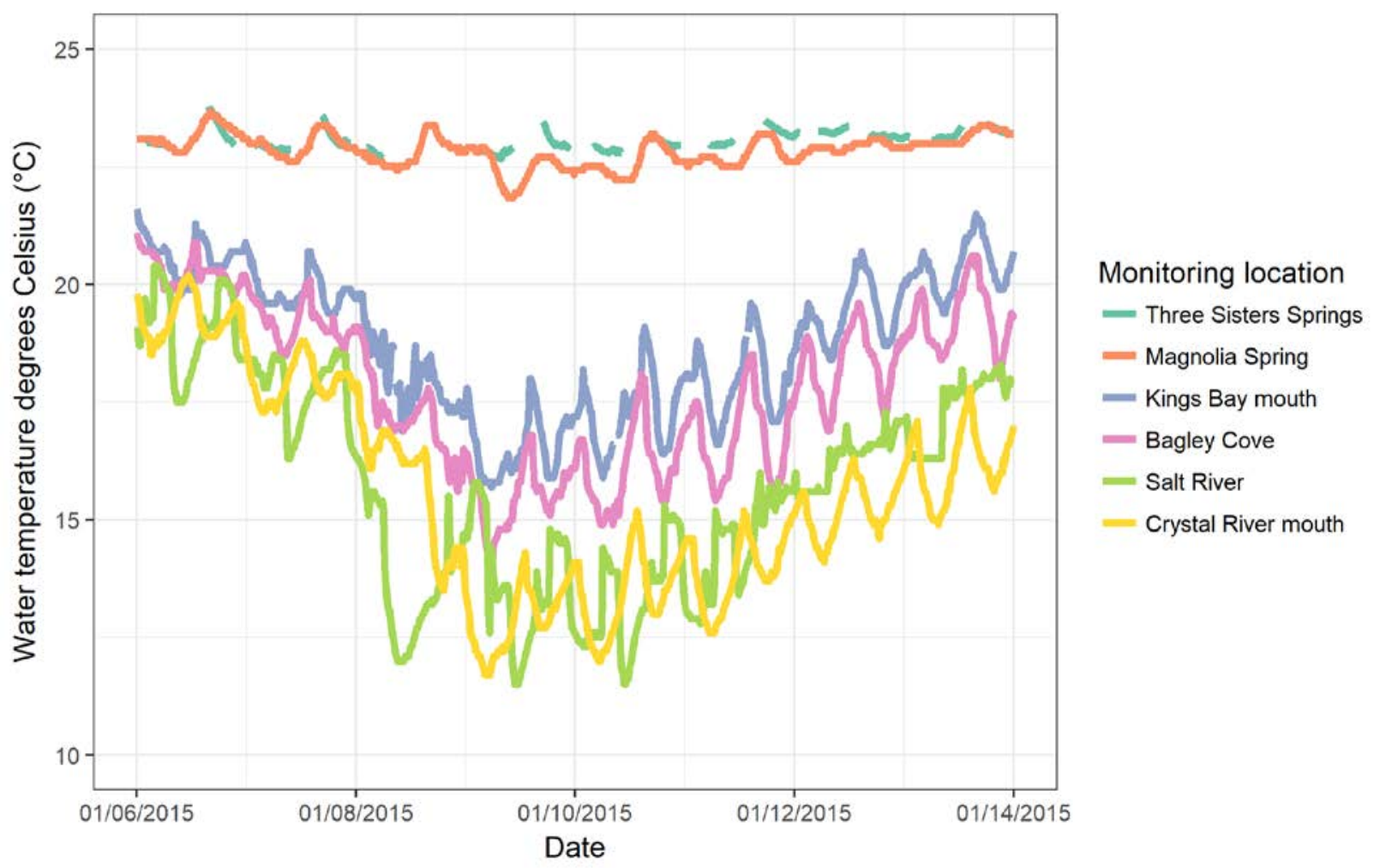

Figure 4. Graph showing water temperatures recorded at the bottom of the water column from U.S. Geological Survey water-monitoring stations (bottom four) and from data loggers placed in the vicinity of springs (top two) during a cold front.

Water level data indicated a wide range of correlation between the stations and Magnolia Spring, but all were able to be successfully transformed to a correlation coefficient of $r>0.9$ (table 1). These high correlation coefficients indicate that in the event that level data are not available from a preferred site, any of the water-level stations in the study area could be used to predict water level at Magnolia Spring or the nearby Three Sisters Springs, after transformation. 
Table 1. Fitted parameters of equation 1 used to transform water-level data from level recording stations in and around Kings Bay, Florida, to the level at Magnolia Spring, Fla.

[Pearson's correlation coefficients $(r)$ of the raw data and the fitted model are also shown]

\begin{tabular}{lccccc}
\hline \multicolumn{1}{c}{ Station } & $\begin{array}{c}\text { Lag } \\
\text { (hours) }\end{array}$ & Amplitude & $\begin{array}{c}\text { Mean } \\
\text { (feet) }\end{array}$ & Raw data $r$ & Model $r$ \\
\hline Cedar Key & -2 & 0.684 & 0.139 & 0.744 & 0.923 \\
Crystal River mouth & 2 & 0.812 & -0.017 & 0.529 & 0.954 \\
Salt River & 1 & 0.928 & -0.110 & 0.825 & 0.959 \\
Bagley Cove & 1 & 0.900 & -0.105 & 0.842 & 0.966 \\
Kings Bay mouth & 1 & 0.875 & 0.029 & 0.873 & 0.955 \\
\hline
\end{tabular}

The level recording station physically closest to Magnolia Spring is Kings Bay mouth. Unsurprisingly, this station had the highest raw correlation coefficient of $r=0.873$ and also a high correlation after model fitting. This location was offline, and data were missing from May 19, 2016, through May 4, 2017, an important time period in our database. Therefore, all water-level analyses used data from Bagley Cove, the second-closest water-level station, which had a nearcomplete record during our study time period. It also had the highest correlation after transformation to Magnolia Spring water level ( $r=0.966$; fig. 5).

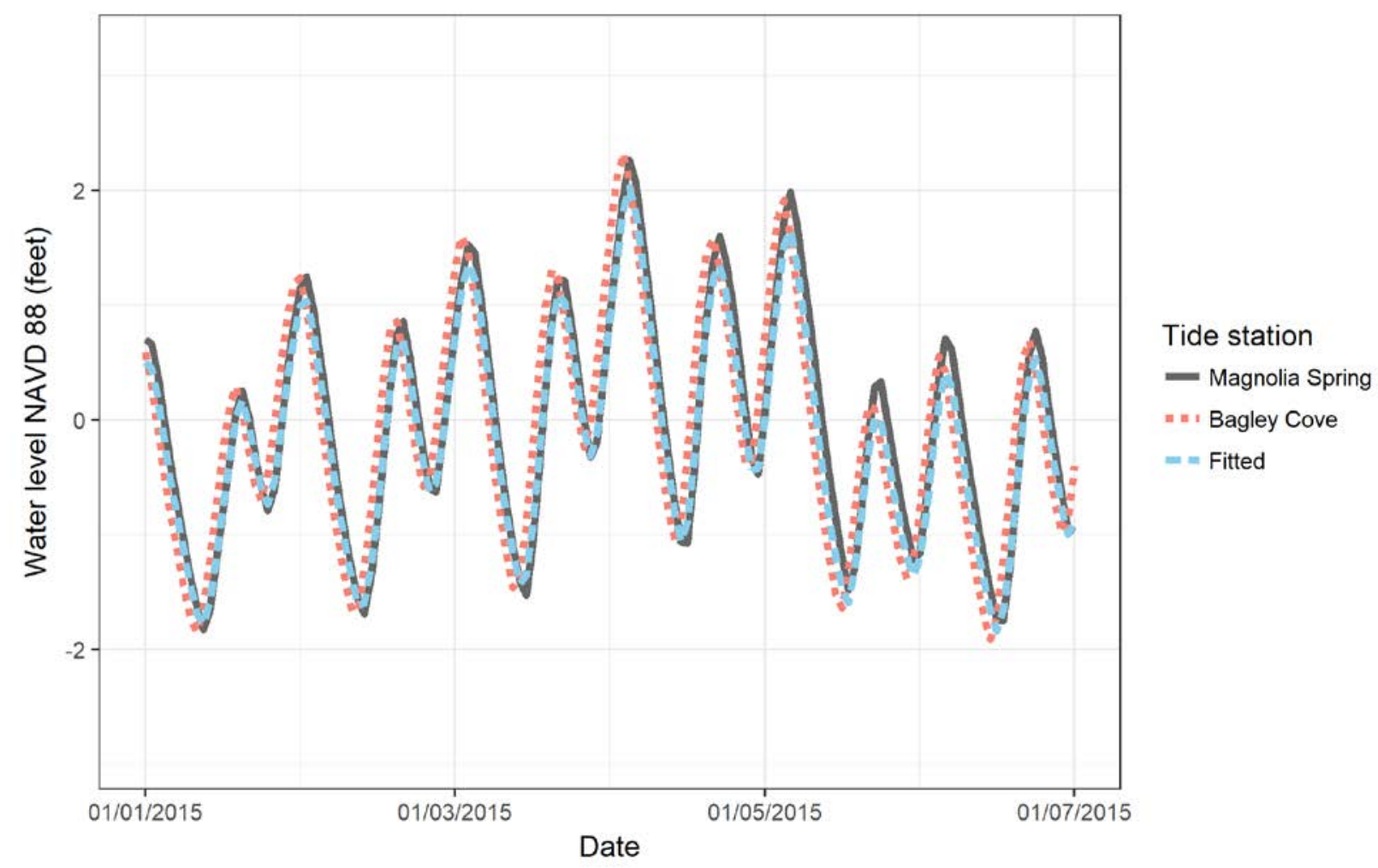

Figure 5. Graph showing example of tide stage in North American Vertical Datum of 1988 (NAVD 88) during 1 week at the mouth of Bagley Cove, Florida (U.S. Geological Survey station 02310747), compared to authors' data logger (Onset U20-001-02-TI) placed in the vicinity of Magnolia Spring, Florida. Fitted model is a translation from Bagley Cove data to Magnolia Spring data. 
Manatees were found in most location polygons during both warm and cold Gulf water temperatures, but they showed the expected pattern of more locations in Crystal River or offshore when Gulf temperatures were relatively warm, and relatively more locations in the springs when Gulf temperatures were relatively cold (fig. 6).

A more detailed look at manatee GPS locations revealed that when Gulf water temperatures were colder than $20^{\circ} \mathrm{C}$, the proportion of locations in springs (especially Three Sisters/Idiots Delight) increased (fig. 7). The point of inflection below which more manatee locations were in the Three Sisters/Idiots Delight polygon than offshore was $17^{\circ} \mathrm{C}$. This shift of locations towards Three Sisters/Idiots Delight increased dramatically when Gulf temperatures were extremely cold $\left(<10^{\circ} \mathrm{C}\right)$, though there were relatively fewer data points overall at those extreme temperatures (fig. 8). Below $14{ }^{\circ} \mathrm{C}$, less than 5 percent of manatee locations were offshore or in the rivers, and below $8{ }^{\circ} \mathrm{C}$ even Kings Bay was not used by the manatees in this data set. Above $8{ }^{\circ} \mathrm{C}$, use of Kings Bay remained relatively constant at approximately 25 percent of all locations, whereas locations within spring polygons decreased and use of offshore locations increased with increasing temperatures. Interestingly, there was also an increase in the use of House/Hunter/Jurassic Springs at Gulf water temperatures greater than $24{ }^{\circ} \mathrm{C}$.

Manatee movements in and out of springs showed a slight relationship with hour of the day (fig. 9). There was a trend of manatees entering springs early in the morning and leaving in the afternoon. This trend was robust across all Gulf water temperature blocks.

There was a strong association of manatee movements in and out of the Three Sisters/Idiots Delight polygon with tide cycle (fig. 10). Note that these analyses recorded when manatees entered or left the Three Sisters polygon via the canal and not when they passed through the narrow entrance to Three Sisters Springs. The strongest pattern was that manatees tended to enter the spring polygon during an incoming tide, and leave the polygon during an outgoing tide. During an incoming tide, manatees tended to enter the polygon during midtide, and leave the polygon at or after midtide. On an outgoing tide, they tended to enter the polygon before or at midtide, and leave at midtide. These patterns were robust even after compensating for the relative amounts of data available at different tide levels.

By contrast, manatee locations — whether inside or outside the Three Sisters/Idiots Delight polygon-were not strongly related to tide (fig. 11). However, there was a strong trend of fewer locations outside the polygon at colder temperatures compared to the numbers found inside the polygon, as seen previously (figs. 6-8).

Movements of telemetered manatees were consistent with hypotheses suggested by previous reporting (Syverson and Wolfe, 2015; Trisha Phy, U.S. Fish and Wildlife Service, written commun., 2017). Specifically, that temperature, time of day, and tide are important predictors of manatee movements in the study area, and midtide is a reliable predictor of manatee movements in and out of Three Sisters Springs. Future work will incorporate observations of manatee movements and human visitation to Three Sisters Springs, and analysis of tagged manatee movements at smaller spatial scales, separating Three Sisters Springs from the Idiots Delight manatee sanctuary and nearby canals. 


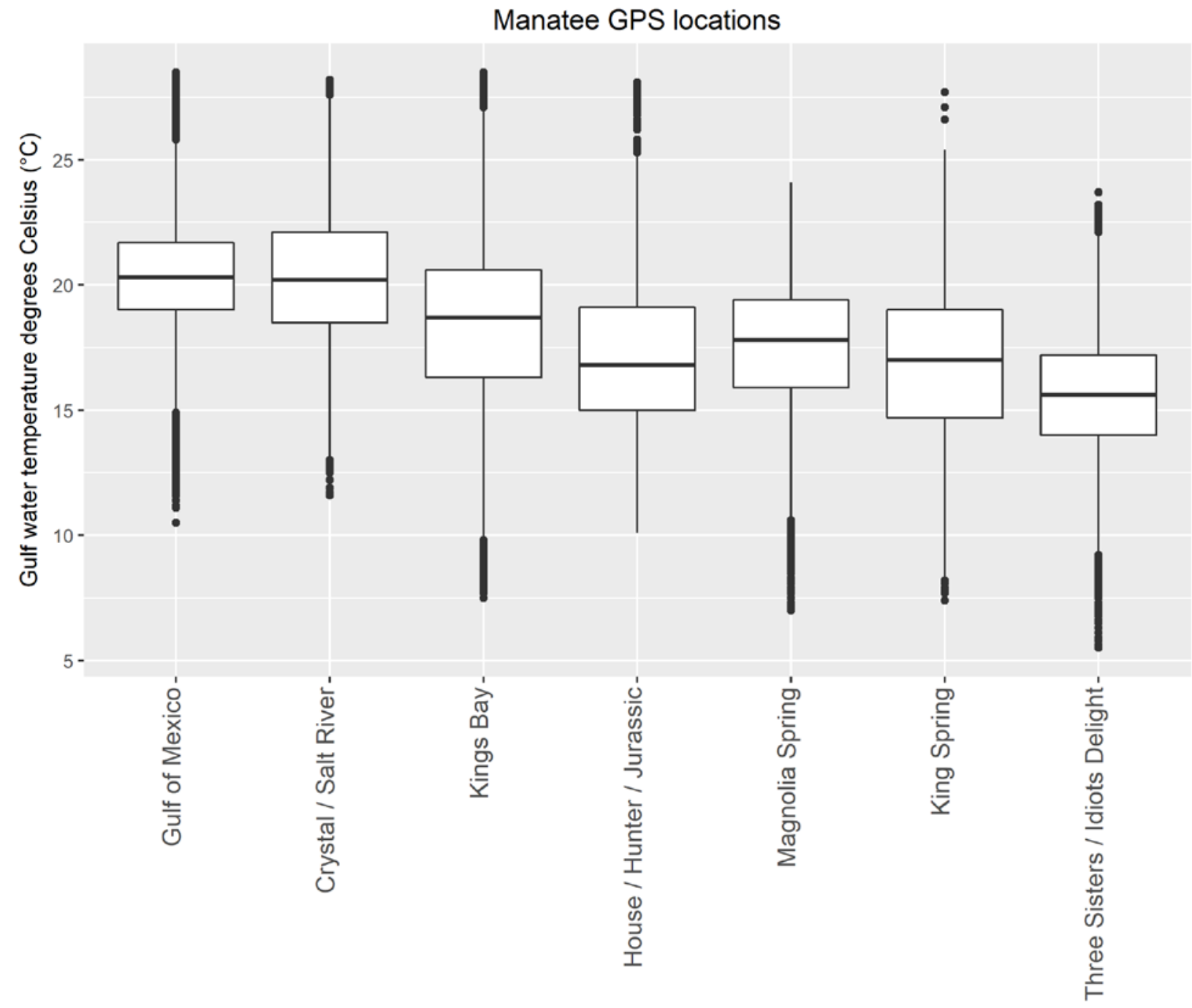

Figure 6. Boxplots of manatee locations were recorded in each of seven location polygons in and around the Crystal River National Wildlife Refuge (CRNWR) compared to Gulf water temperatures recorded from the Crystal River mouth, U.S. Geological Survey station 285531082412600. Manatee use of offshore locations (left) was generally during warmer conditions while use of springs (right) was generally during colder conditions. [GPS, Global Positioning System] 


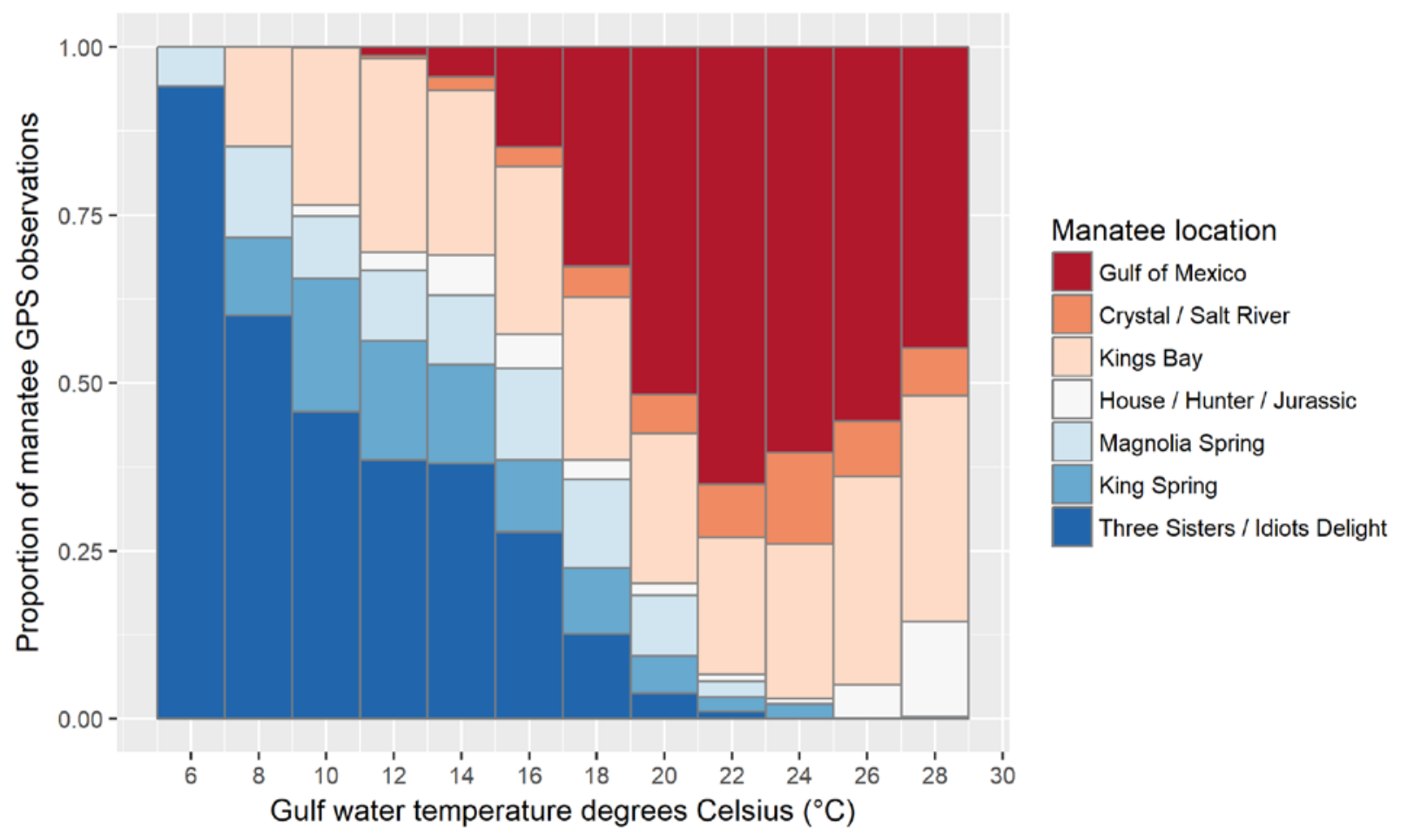

Figure 7. Graph showing proportion of manatee Global Positioning System (GPS) locations plotted in each of seven location polygons at a range of Gulf water temperatures recorded from the Crystal River mouth, Florida, U.S. Geological Survey (USGS) station 285531082412600. The proportion of locations inside springs polygons, especially Three Sisters/ldiots Delight, increased sharply at colder Gulf temperatures. 


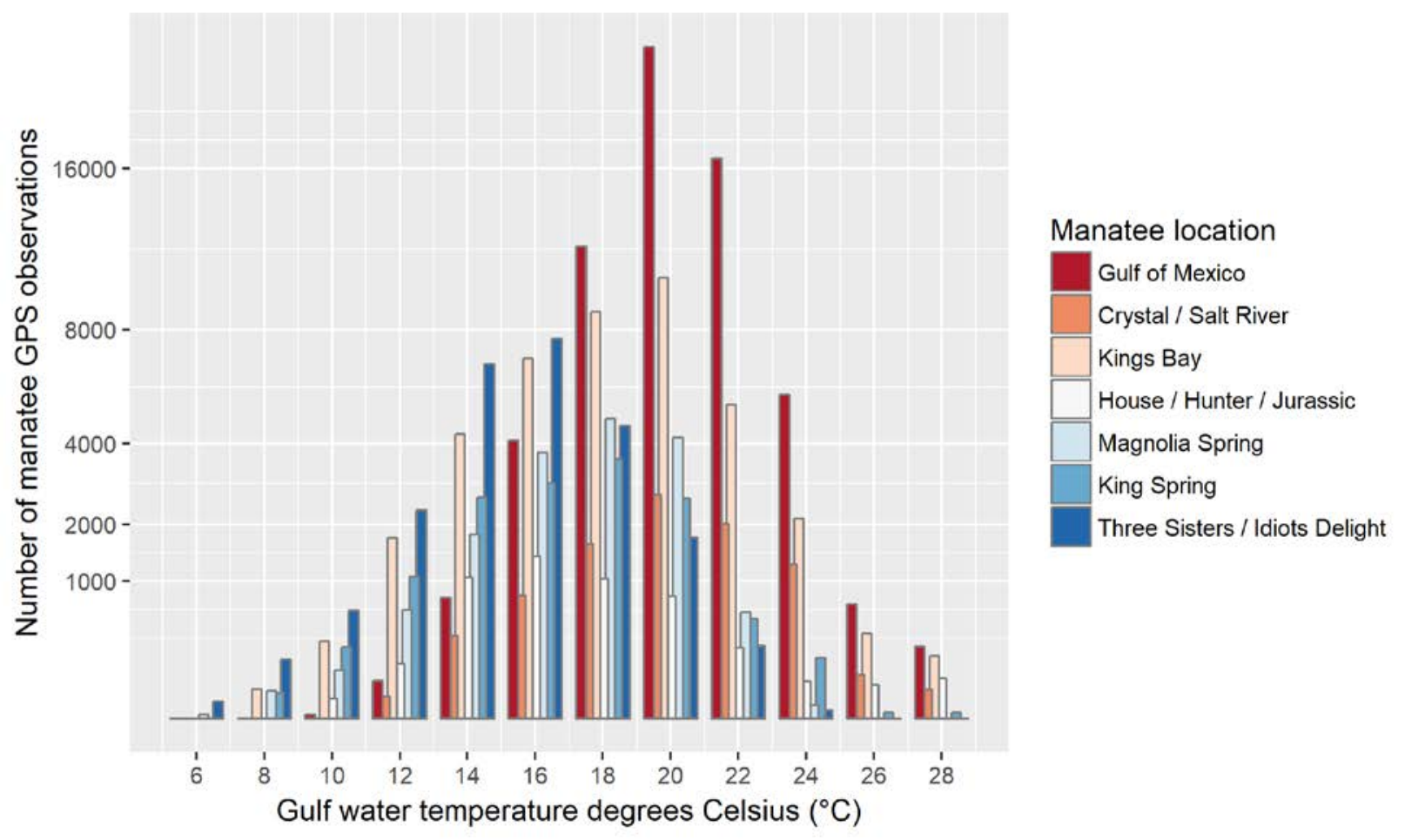

Figure 8. Graph showing number of manatee Global Positioning System (GPS) locations plotted in each of seven location polygons at a range of Gulf water temperatures recorded from the Crystal River mouth, Florida, U.S. Geological Survey (USGS) station 285531082412600. The overall bell shape of the plot is due to the data distribution of Gulf water temperatures. 


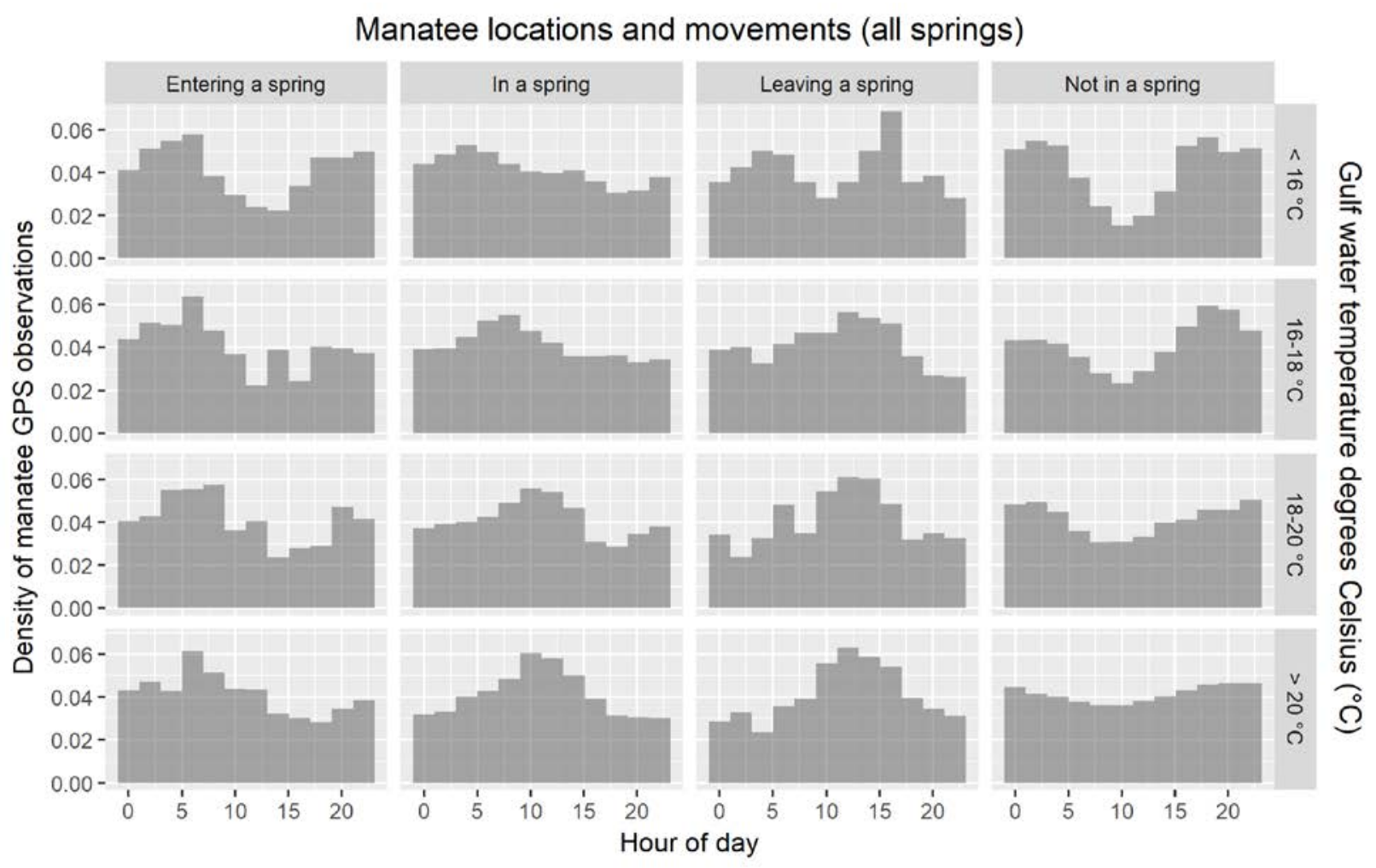

Figure 9. Graphs showing density of manatee Global Positioning System (GPS) locations and movements relative to the four spring polygons by hour of the day and blocks of Gulf water temperatures recorded from the Crystal River mouth, Florida, U.S. Geological Survey (USGS) station 285531082412600. The top labels refer to movements (entering or leaving a spring) and stationary locations (in a spring or not in a spring). Right labels refer to blocks of Gulf water temperature. All springs were combined for this analysis. 


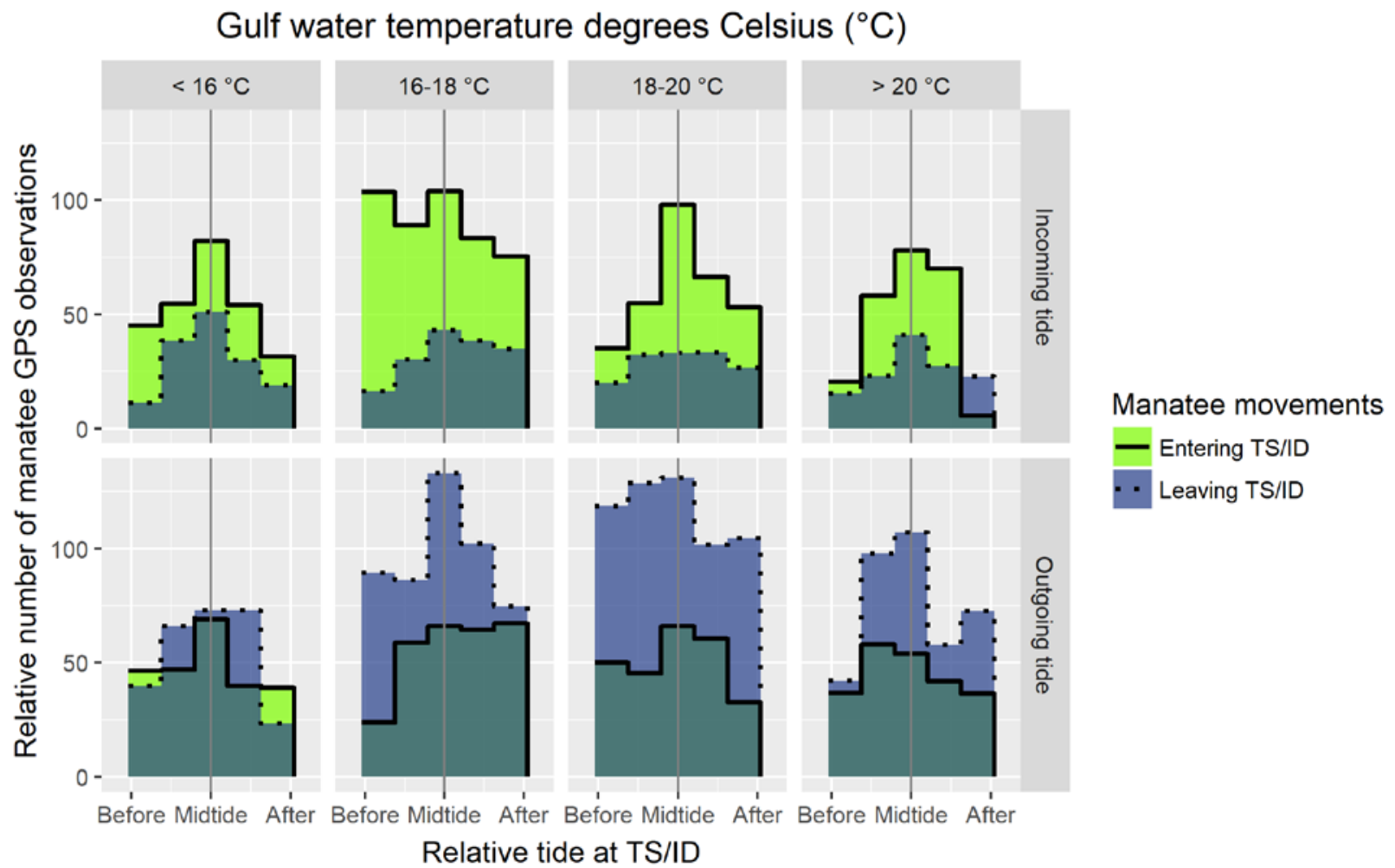

Figure 10. Graphs showing number of manatee Global Positioning System (GPS) movements relative to the Three Sisters/ldiots Delight polygon (TS/ID) at different blocks of Gulf water temperatures recorded at the Crystal River mouth, Florida, U.S. Geological Survey (USGS) station 285531082412600, and tide stage at Magnolia Spring (used as proxy for TS/ID). The histogram colors refer to movements (entering or leaving TS/ID). Right labels refer to whether the tide was incoming or outgoing when the movement was recorded. 


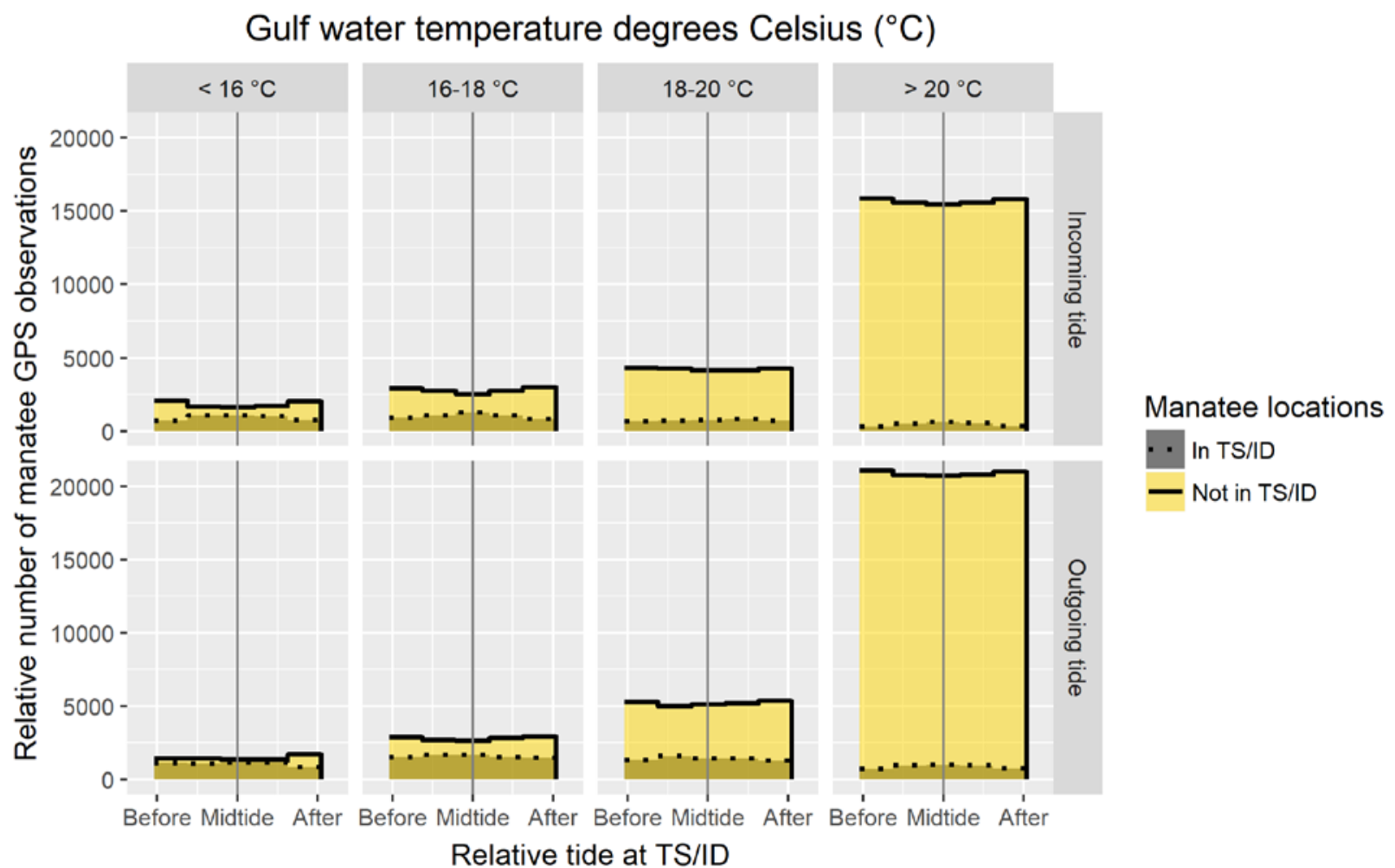

Figure 11. Graphs showing number of manatee Global Positioning System (GPS) locations relative to the Three Sisters/Idiots Delight polygon (TS/ID) at different blocks of Gulf water temperatures recorded at the Crystal River mouth, Florida, U.S. Geological Survey station 285531082412600, and tide stage at Magnolia Spring (used as proxy for TS/ID). The histogram colors refer to locations (in TS/ID or not in TS/ID). Right labels refer to whether the tide was incoming or outgoing when the location was recorded. 


\section{References Cited}

Byrd, R.H., Lu, Peihuang, Nocedal, Jorge, and Zhu, Ciyou, 1995, A limited memory algorithm for bound constrained optimization: SIAM Journal on Scientific Computing, v. 16, p. $1190-1208$.

Dowle, Matt, and Srinivasan, Arunkumar, 2017, data.table: Extension of `data.frame` [R package version 1.10.4]: Accessed October 1, 2017, at https://CRAN.R-project.org/package=data.table.

Marmontel, Miriam, Reid, James, Sheppard, J.K., and Morales-Vela, Benjamin, 2012, Tagging and movement of sirenians, p. 116-125 in Hines, E.M., Reynolds III, J.E., Aragones, L.V., Mignucci-Giannoni, A.A., and Marmontel, M., eds., Sirenian conservation: Issues and strategies in developing countries: Gainesville, Fla., University Press of Florida.

R Core Team, 2017, R: A language and environment for statistical computing: Vienna, Austria, R Foundation for Statistical Computing, accessed October 1, 2017, at https://www.Rproject.org/

Reid, J.P., Bonde R.K., and O’Shea, T.J., 1995, Reproduction and mortality of radio-tagged and recognizable manatees on the Atlantic coast of Florida, p. 171-191 in O’Shea, T.J., Ackerman, B.B., and Percival, H.F., eds., Population biology of the Florida manatee (Trichechus manatus latirostris): National Biological Service Information and Technology Report 1.

Slone, D.H., 2017, Water temperature in Three Sisters Springs, water temperature and level in Magnolia Spring-winter 2014-15: U.S. Geological Survey data release accessed November 7, 2017, at https://doi.org/10.5066/F78P5ZGR.

Syverson, R.E., and Wolfe, Carl, 2015, Manatees, people, and Three Sisters Springs: U.S. Fish and Wildlife Service report, accessed October 1, 2017, at https://www.fws.gov/uploadedFiles/Final\%2028\%20pages.pdf.

Tomkiewicz, S.M., Fuller, M.R., Kie, J.G., and Bates, K.K., 2010, Global Positioning System and associated technologies in animal behaviour and ecological research: Philisophical Transactions of the Royal Society B, v. 365, p. 2163-2176.

Wickham, Hadley, 2009, ggplot2: Elegant graphics for data analysis: New York, SpringerVerlag. 